\title{
A review of the Health Act 2017 using the availability, accessibility, acceptability and quality framework
}

\author{
Claire Adionyi*
}

\section{Introduction}

The International Covenant on Economic, Social and Cultural Rights (ICESCR) provides for the right to the highest attainable standard of health. ${ }^{1}$ Kenya has ratified this Covenant and is, therefore, bound by its provisions. ${ }^{2}$ The Constitution of Kenya (2010) further establishes a framework for expanding rights and freedoms under Article 24 (4). ${ }^{3}$

The Constitution expressly provides for the right to health under Article 43 (1), which led to the enactment of the Health Act in 2017 (the Act). Article 43 (1) (a) of the Constitution states:

Every person has the right to the highest attainable standard of health, which includes the right to health care services, including reproductive health care. ${ }^{4}$

The Constitution, therefore, sets out the normative standard that the Act seems to adopt. In light of the poor state of Kenya's health-care system, this extensive legislative framework requires a certain standard to be upheld by healthcare facilities in Kenya. This development update seeks to assess how the Act measures to international standards of health.

From Article 43 of the Constitution, the minimum standard envisioned by the Constitution is 'the highest attainable standard of health.' The right is yet to

Article 12, International Covenant on Economic, Social and Cultural Right, 16 December 1966, 999 UNTS 171.

2 Article 2(5) \& (6), Constitution of Kenya (2010).

3 Article 24(4), Constitution of Kenya: 'The State shall enact and implement legislation to fulfil its international obligations in respect of human rights and fundamental freedoms'.

4 Article 41(3), Constitution of Kenya (2010).

* The author teaches at Strathmore Law School. 
receive concrete municipal interpretation since the recognition of the right to health under the Constitution is relatively recent. This paper, therefore, favours the definition proffered by the Committee on the Economic, Social and Cultural Rights (CESCR) in paragraph 4 of General Comment 14 where it has been defined as:

The right to health embraces a wide range of socio-economic factors that promote conditions in which people can lead a healthy life, and extends to the underlying determinants of health, such as food and nutrition, housing, access to safe and potable water and adequate sanitation, safe and healthy working conditions, and a healthy environment. ${ }^{5}$

Constitutionalisation of the right to health makes it an entitlement thus ensuring that its implementation avoids the arbitrariness that oft surrounds the enforcement of economic, social and cultural rights. ${ }^{6}$ Such arbitrariness is inconsistent with human rights' raison d'être. ${ }^{7}$ Constitutionalisation of the right to health impacts health policy and provides an enabling environment for better health outcomes. ${ }^{8}$ The entrenchment of a constitutional right to health is already a high normative standard and as a study that analysed data from 144 countries found, this entrenchment contributes significantly to wellbeing.

The CESCR offers an interpretation of the right to the highest attainable standard of health in its General Comment 14. ${ }^{10}$ The General Comment 14 is not a binding source of law but it is an authoritative interpretative text. At paragraph 12, the General Comment 14 sets out a standard that has come to be referred to as the 'AAAQ framework.' According to the AAAQ framework, 'the right to health in all its forms and at all levels contains four interrelated and essential elements: availability, accessibility, acceptability and quality. ${ }^{\text {'11 }}$ Notably, the AAAQ framework has been the subject of judicial scrutiny. For instance, the

General Comment 14, International Covenant on Economic, Social and Cultural Rights, para.12.

6 Kavanagh M, 'The right to health: Institutional effects of constitutional provisions on health outcomes' 51(3) Studies in Comparative International Development, 2016, 355.

7 Kavanagh M, 'The right to health', 355.

8 Kavanagh M, 'Constitutionalizing health: Rights, democracy and political economy of health policy' Publicly Accessible Penn Dissertations, 2863 (2017) -<https://repository.upenn.edu/cgi/viewcontent.coi? article $=4649 \&$ context $=$ edissertations $>$ on 23 March 2020.

$9 \quad$ The study found that both 'assembled qualitative and case-study evidence supported the idea that institutional environments shaped by a right to health encourage more and better delivery of health services which in part accounts for the positive impact on health outcomes. See Kavanagh M, 'The right to health', 328 .

10 Office of the High Commissioner for Human Rights, CESCR General Comment No 14: The right to the bighest attainable standard of health (Art.12), 11 August 2000, at para 12 -<https://www.refworld.org/ pdfid/4538838d0.pdf > on 23 March 2020.

11 CESCR General Comment No 14, para.12 
High Court in Maimuna Awuor \& another $v$ Attorney General \& others Petition No 562 of 2012) unpacked the right to health holding that:

...ICESCR requires state parties to ensure that health services are available, accessible, acceptable, and of good quality. It interprets availability to encompass ....not only...timely and appropriate health care but also...the underlying determinants of health such as access to safe and potable water and adequate sanitation, an adequate supply of safe food, nutrition and housing, healthy occupational and environmental conditions and access to health-related ... information... ${ }^{12}$

In light of this framework, this paper reviews the newly-enacted Health Act in a bid to measure whether the framework's standards have been met.

\section{Availability}

The availability element suggests that functioning public health and healthcare facilities, goods and services, as well as programmes, have to be available in sufficient quantity within a state party. ${ }^{13}$ The key indicators of the presence of this element include: the underlying determinants of health such as the availability of hospitals, clinics and other health-related buildings, trained medical and professional personnel receiving domestically competitive salaries, and availability of essential drugs. ${ }^{14}$ The availability criterion similarly takes into account the developmental level of state parties. It allows for a margin of appreciation as to the precise nature of the facilities, goods and services in that these will vary depending on numerous factors including the state party's developmental level. ${ }^{15}$

The Act upholds this element mainly through delineating the state's obligation on the right to health. The Act sets out by reiterating the constitutional standard of health-care by stating that its objective is to protect, respect, promote and fulfil the health rights of all persons in Kenya to the progressive realisation of their right to the highest attainable standard of health. ${ }^{16}$ The objective makes two notable additions to the standard, that is, the inclusion of the common tripartite obligation of respecting, promoting and fulfilling the right which points to the fact that the Act seems to be employing a human rights-based-approach for the realisation of this right. ${ }^{17}$

\footnotetext{
Maimuna Awnor \& another v Attorney General \& others [2016] eKLR.

CESCR General Comment No 14, para.12.

CESCR General Comment No 14, para.12.

CESCR General Comment No 14, para.12.

Section 3(b), Health Act (Act No 21 of 2017).

Hunt P, 'Interpreting the international right to health in a human rights-based approach to health' 18

(2) Health and Human Rights Journal, 2016, 109-130.
} 
The Act also refers to the concept of progressive realisation. This taps into a debate on the justiciability of economic, social and cultural rights, and the fact that they are often resource-intensive and the law acknowledges the constraints in their realisation due to the limited resources. ${ }^{18}$ This relates to the concept of margin of appreciation in the availability criterion as it allows for the developmental level of a state party to be taken into consideration. However, the CESCR categorically noted that, 'states have immediate obligations in relation to the right to health and the obligation to take steps which steps must be deliberate, concrete and targeted towards the full realisation of the right to health. ${ }^{19}$ Similarly, the High Court of Kenya in Michael Mutinda Mutemi \& another $v$ Permanent Secretary, Ministry of Education $\& 4$ others, discredited the use of progressive realisation as a defence for non-fulfilment of socio-economic rights. ${ }^{20}$ The High Court further stated in Mitubell Welfare Society v Attorney General \& 2 others (Petition No 164 of 2011) that progressive realisation should not be interpreted in a manner that leads to the deprivation of the right. ${ }^{21}$

The Act thus places on the state a fundamental duty to observe, respect, protect, promote and fulfil the right to health. ${ }^{22}$ As part of this fundamental duty, the state is required to take a number of steps that have a direct influence on the availability of healthcare. This includes the regulations-aspect of availability such as the developing of policies, laws and other measures. ${ }^{23}$ As detailed in their duty to ensure full realisation of the right, states must invest in the building blocks of an effective health system. ${ }^{24} \mathrm{~A}$ health system, as defined by the World Health Organisation (WHO), encompasses all the organisations, people and actions whose primary intent is to promote, restore or maintain health. ${ }^{25}$ The state is required to establish policies directed at the determinants of health, regulatory frameworks and health legislation. ${ }^{26}$ The state is also tasked with ensuring that there exists an

\footnotetext{
18 Office of the United Nations High Commissioner for Human Rights, Frequently asked questions on economic, social and cultural rights, Fact Sheet No.33. - < https://www.ohchr.org/Documents/Publications/FactSheet33en.pdf >- on 23 March 2020.

CESCR General Comment No 14, para 30.

Michael Mutinda Mutemi \& another v Permanent Secretary, Ministry of Education \& 4 others [2015] eKLR.

Mitubell Welfare Society v Attorney General \& 2 others [2012] eKLR.

Section 4, Health Act (Act No 21 of 2017).

Section 4(a), Health Act (Act No 21 of 2017).

World Health Organisation, Advancing the right to health: The vital role of the law, 2017, $11-<$ https:// apps.who.int/iris/bitstream/handle/10665/252815/9789241511384-eng.pdf;jsessionid=A83FB1A C7AB8B5691C7314E9D738A273? sequence=1> on 23 March 2020.

25 World Health Organisation, Everybody's business: Strengthening health systems to improve bealth outcomes: WHO's framework for action, 2007, 2.

26 World Health Organisation, Advancing the right to bealth, 11.
} 
enabling environment consisting of the minimum human resource, infrastructure, commodities and supplies for the facilities as per the norms and standards sets out in the Act. ${ }^{27}$ Accordingly, the Act envisages that the state should take steps to ensure the availability of appropriate regulation because this is indicative of a functioning health system.

Another salient feature of the Act that falls under this criterion is the provision on trained health professionals. The Act goes a step further and provides a standard definition for trained health professionals and methods to accurately assess the size and composition of this workforce through the various regulatory bodies it establishes: ${ }^{28}$

... a health professional with formal medical training at the proficiency level of a medical officer, a nurse, midwife, or a clinical officer who has been educated and trained to proficiency in the skills needed to manage pregnancy-related complications in women, and who has a valid license from the recognised regulatory authorities to carry out that procedure. ${ }^{29}$

It has been argued that the idea that health systems are unable to function without workers sounds remarkably obvious but the realisation that the workforce is critical to saving lives is often taken for granted. ${ }^{30}$ Despite their importance, there is a shortage of trained health professionals in Kenya. ${ }^{31}$ For instance, the WHO recommended ratio is 44.5 nurses, physicians and doctors for 10,000 people. ${ }^{32}$ Kenya is at a distant 13.8 per 10,000 people. ${ }^{33}$

The distribution inequalities are far worse in the various counties leading to low quality treatment in remote regions. ${ }^{34}$ Beyond these shortages, there are other factors that prevent health professionals from peak performance; they are often

27 Section 6(3), Health Act (Act No 21 of 2017).

28 For instance the Kenya Health Professions Oversight Authority, see Part VI, Health Act (Act No 21 of 2017).

29 Section 6(2), Health Act (Act No 21 of 2017).

30 World Health Organisation, World report on knowledge for better health, 38.

31 Chankova S, Muchiri S and Kombe G, 'Health workforce attrition in the public sector in Kenya: A look at the reasons' 7(58) Human Resources for Health, 2009. See also Mumbo M, Were S, Murianki C, Mutuku M and Mutwiwa S, 'The implication of the shortage of health workforce specialist on universal health coverage in Kenya' 15(80) Human Resources for Health, 2017, 2. -<https://humanresources-health.biomedcentral.com/articles/10.1186/s12960-017-0253-9>- on 23 March 2020.

32 World Health Organisation, A universal truth: No bealth without a workforce, $2013-<$ https://www.who.int/ workforcealliance/knowledge/resources/GHWA_AUniversalTruthReport.pdf>- on 23 March 2020.

33 Kenya Ministry of Health, Kenya Health Workforce report: The status of healthcare professionals in Kenya, 2015 - < https://www.taskforce.org/wp-content/uploads/2018/07/KHWF_2017Report_ Fullreport_042317-MR-comments.pdf. >- on 23 March 2020.

34 Child Fund International, 'Struggles facing the Kenyan healthcare system' Child Fund International, 4 January 2013 - < https://www.childfund.org/Content/NewsDetail/2147490088/ > on 23 March 2020. 
exposed to poor working conditions, which mainly encompass ill-equipped facilities, poor remuneration or non-payment of salaries. ${ }^{35}$ For instance, Kenyan doctors went on a record 100-day strike, which is the longest-ever medical strike in Kenya's history, and at the core of their complaints was the issue of pay and poor working conditions. ${ }^{36}$ Prior to this, nurses had gone on a 5-month strike agitating the same problems: poor pay and poor working conditions. ${ }^{37} \mathrm{~A}$ combination of the understaffing, poor wages and inadequate facilities can then have an overall demoralising effect and burnout among health professionals..$^{38}$

The Act, however, seeks to improve health professional's outputs. For instance, the government should meet its bare minimum obligations to this workforce by providing an enabling environment. ${ }^{39}$ These obligations perceive that health professionals will be well remunerated for their services, that there will be availability of drugs and supplies and consequently that there will be an improvement of working conditions. By ensuring the availability of an enabling environment, the Act foresees that this workforce will be motivated leading to the realisation of the right to health.

\section{Accessibility}

Accessibility requires that health facilities, goods and services have to be accessible to everyone without discrimination, within the jurisdiction of the state party..$^{40}$ In expounding on this criterion, the CESCR held that it entails four overlapping dimensions and these are:

Non-discrimination: health facilities, goods and services must be accessible to all, especially the most vulnerable or marginalised sections of the population, in law and in fact, without discrimination on any of the prohibited grounds;

35 These are the two main things that both doctors and nurses were agitating for in their recent prolonged strikes, poor working conditions and better pay.

36 Merab E and Nyamai F, 'Relief for patients as doctors call off strike' Daily Nation, 14 March 2017 - < https://www.nation.co.ke/news/Doctors-strike-ends-KMPDU/1056-3849540-hnbxdpz/index. html.>- on 23 March 2020.

37 Kimanthi $\mathrm{K}$ and Nyamai F, 'Kenyan nurses end their 5-month strike after deal with state' Daily Nation, 2 November 2017 -< https://www.nation.co.ke/news/Kenyan-nurses-end-4-month-strikeafter-deal-with-State/1056-4166940-mo35skz/index.html >- on 23 March 2020.

38 Lyndon A, 'Burnout among health professionals and its effect on patient safety', Patient Safety Network, 1 January 2015 -< https://psnet.ahrq.gov/perspectives/perspective/190/burnout-amonghealth-professionals-and-its-effect-on-patient-safety >- on 23 March 2020.

40 CESCR General Comment No 14, para.12. 
Physical accessibility: health facilities, goods and services must be within safe physical reach for all sections of the population, especially vulnerable or marginalised groups, such as ethnic minorities and indigenous populations, women, children, adolescents, older persons, persons with disabilities and persons with HIV/AIDS. Accessibility also implies that medical services and underlying determinants of health, such as safe and potable water and adequate sanitation facilities, are within safe physical reach, including in rural areas. Accessibility further includes adequate access to buildings for persons with disabilities;

Economic accessibility (affordability): health facilities, goods and services must be affordable for all. Payment for health-care services, as well as services related to the underlying determinants of health, has to be based on the principle of equity, ensuring that these services, whether privately or publicly provided, are affordable for all, including socially disadvantaged groups. Equity demands that poorer households should not be disproportionately burdened with health expenses as compared to richer households;

Information accessibility: accessibility includes the right to seek, receive and impart information and ideas concerning health issues. However, accessibility of information should not impair the right to have personal health data treated with confidentiality. ${ }^{41}$

The High Court in the Maimuna Awuor case expounded on the accessibility criterion by holding that:

Accessibility requires non-discriminatory access to health facilities, goods and services ... especially [for] the most vulnerable or marginalised sections of the population. In addition, accessibility also requires that health services be available and free from discrimination; they must be physically accessible; and they must also be economically accessible, that is they must be affordable. ${ }^{42}$

The Act addresses this criterion in all its dimensions in various ways. The theme of trained health professionals discussed above is one of the ways the Act provides for accessibility. ${ }^{43}$ The presence of trained professionals in Kenya's health system means that the requirements of non-discrimination and information accessibility will be met. Consequently, the service providers in this sector will, as a result of the training, be able to uphold fundamental standards such as ensuring that users of health facilities, goods and services are treated without discrimination. These users are also able to access all the relevant information while their confidential information is protected.

By making provision of a health service package and financing, the Act addresses the dimensions of physical and economic accessibility. It places an obligation on the state to ensure the provision of a health service package at all

\footnotetext{
41 CESCR General Comment No 14, para 12 (b).

42 Maimuna Awuor \& another $v$ Attorney General \& others [2016] eKLR.

43 Sections 6(2), 6(3) \& 47, Health Act (Act No 21 of 2017).
} 
levels of the healthcare system and categorically includes physical and financial access to healthcare. ${ }^{44}$ There is widespread agreement with the principle that a sick person should be able to receive appropriate access to healthcare without compromising their own or their family's livelihoods. ${ }^{45}$ The availability of universal healthcare in Kenya shall improve the quality of healthcare. Statistics show that an estimated 2.5 million Kenyans are pushed below the national poverty threshold as a result of exorbitant out-of-pocket healthcare expenditure and annually 1.48 million Kenyans are pushed into poverty. ${ }^{46}$ With respect to health financing, Section 6 (3) of the Act places an obligation on the government to ensure the existence of an enabling environment consisting of the minimum human resource, infrastructure, commodities and supplies.

It is notable that prior to the enactment of the Act, the Kenyan Government failed spectacularly on this front. With respect to the ratio of physician to people, a report conducted in 2015 showed that Kenya had only 2,089 specialist doctors; this shows an inability to deal with non-communicable diseases. ${ }^{47}$ For instance, Kenya had only 71 psychiatrists yet about 4.4 per cent of Kenyans (over 2 million people) have a mental health problem. ${ }^{48}$ The report also showed that cancer killed about 15,714 people in 2015 and yet there were only 9 experts in radiotherapy or oncology and only 128 in radiology. ${ }^{49}$ A more terrifying fact is Kenya's population is growing by more than 3200 people every day but this does not match the rate at which new doctors are added to the market annually. ${ }^{50}$ With respect to physical accessibility, Kenyatta National Hospital, the biggest referral public hospital in Kenya, is a prime example of this failure. This hospital is placed at Level Six and has a bed capacity of 1410 with daily inpatient traffic of more than 2,000 patients daily. ${ }^{51}$ Considering its status at the apex of the national health-care delivery system, one would therefore imagine that there would be a high standard of healthcare delivery. This is because the level of efficiency is of national importance, particularly because it is the highest referral hospital in the

\footnotetext{
44 Section 4 (d), Health Act (Act No 21 of 2017).

45 World Health Organisation, World report on knowledge for better bealth, 40.

46 Korir J, Maina T, Chen A, Perales N and Dutta A, Healthcare financing options for Kenya: FY 2013/142029/30, October 2014 (Health Policy Project). See also, Kimani D and Maina T, Catastrophic health expenditures and impoverishment in Kenya, February 2015 (Health Policy Project).

47 Kenya Ministry of Health, Kenya Health Workeforce report, 2015.

48 Kenya Ministry of Health, Kenya Health Workeforce report, 2015.

49 Kenya Ministry of Health, Kenya Health Workforce Report, 2015

50 The fact that there are only 10 medical schools and 102 nursing schools in Kenya is a major contributing to these statistics. See Kenya Ministry of Health, Kenya Health Workforce Report, 2015

51 Office of the Auditor General, Performance audit report of the Auditor-General Specialized Healthcare delivery at Kenyatta National Hospital, 2012, 25.
} 
country. ${ }^{52}$ The state of other infrastructure including medical supplies and drugs is similarly poor. ${ }^{53}$

By ensuring access to basic health services irrespective of geographical location or economic status and in line with this criterion, the Act's provisions create an impetus for the state to achieve great strides in improving the access to healthcare in Kenya.

\section{Acceptability}

Acceptability requires that all health facilities, goods and services must be respectful of medical ethics and culturally appropriate, that is, respectful of the culture of individuals, minorities, peoples and communities, sensitive to gender and life-cycle requirements, as well as being designed to respect confidentiality and improve the health status of those concerned. ${ }^{54}$

In light of Kenya's background, the Act acknowledges the use of traditional and alternative medicine. Traditional medicine has been defined as including:

the knowledge, skills and practices based on the theories, beliefs and experiences indigenous to different cultures, whether explicable or not, used in the maintenance of health as well as in the prevention, diagnosis, improvement or treatment of physical and mental illness..$^{55}$

By allowing for and accepting the influence of Kenya's cultural medical practices, the Act ensures that even the indigenous communities in Kenya will accept its provisions. Further, under the state's responsibility for health, the Act categorically recognises cultural communities as one of the protected groups. ${ }^{56}$

Community-based health promotion often emphasises elements of empowerment, participation, multidisciplinary collaboration, capacity building, equity and sustainable development. ${ }^{57}$ Therefore, when laws are imposed upon

Office of the Auditor General, Performance audit report, 2012, 3.

53 Bwire V, 'The major problem at Kenyatta National Hospital is structural and system failures' Citizen Digital, 9 March 2018-<https:// citizentv.co.ke/news/bwire-the-major-problem-at-knh-is-structural-and-system-failures-193222/> - on 23 March 2020. See also Gathura G, 'Report shows Kenyatta National Hospital has other cases of malpractice' Standard Digital, 4 March 2018 -<https://www. standardmedia.co.ke/article/2001271910/report-shows-kenyatta-national-hospital-has-other-casesof-malpractice> on 23 March 2020.

54 CESCR General Comment No 14, para.12.

55 Section 2, Health Act (Act No 21 of 2017).

56 Section 4 (c), Health Act (Act No 21 of 2017).

57 Judd J, Frankish CJ and Moulton G, 'Setting standards in the evaluation of community-based health promotion programmes-A unifying approach' 16(4) Health Promotion International, 2001. 
communities in a manner that fails to appreciate the uniqueness of their communities, there could be tensions in the implementation of these laws. ${ }^{58}$ By providing for the use of traditional medicine and the inclusion of cultural communities as a protected group, the Act seems to be taking active measures to promote its acceptability.

The categorical reference to confidentiality in Section 11 of the Act further promotes its acceptability especially with respect to diseases that are surrounded with stigma such as HIV/AIDS. For instance, although the awareness of HIV/ AIDS is high in Kenya, many people living with HIV face high levels of stigma and discrimination, which prevents them from accessing HIV healthcare services. ${ }^{59}$

This section is critical in light of Kenya's history and more specifically what was termed the 'Uhuru HIV list' in which the President of Kenya issued a directive ordering the collection of up-to-date data and the preparation of a report on all school going children who are living with HIV, information on their guardians, number of expectant mothers who are living with HIV, and the number of breastfeeding mothers living with HIV. ${ }^{60}$ This directive was thought to pose a threat to the fundamental human rights of persons living with HIV in Kenya and was the subject matter of the case of KELIN \& others $v$ Cabinet Secretary for the Ministry of Health \& others (Petition No 250 of 2015). ${ }^{61}$ The High Court, however, found no link between an infringement of privacy and an ability to enjoy the highest attainable standard of health. ${ }^{62}$ The Court failed to consider the adverse consequences a violation of the right to privacy can have on those seeking health services particularly for persons living with HIV. ${ }^{63}$

Accordingly, the assurance of confidentiality in the health-care system and consequent enforcement will go a long way in mitigating some of the challenges faced in the fight against diseases in the country.

58 Judd J, Frankish CJ and Moulton G, 'Setting standards in the evaluation of community-based health promotion programmes'.

59 National AIDS Control Council of Kenya, Kenya AIDS response progress report, 2016, 5 - <https:// nacc.or.ke/wp-content/uploads/2016/11/Kenya-AIDS-Progress-Report_web.pdf.>- on 23 March 2020.

${ }_{60}$ Kenya Legal and Ethical Issues Network on HIV and AIDS (KELIN), Mapping the constitutional provisions on the right to health and the mechanisms for implementation in Kenya: Case study report, 2018, 18. - < http://www.equinetafrica.org/sites/default/files/uploads/documents/KELIN\%20Kenya $\% 20$ rights $\% 20$ case $\% 20$ study $\% 202018$.pdf. > on 23 March 2020.

${ }^{61}$ KELIN \& others $v$ Cabinet Secretary for the Ministry of Health \& others [2016] eKLR.

${ }^{62}$ KELIN \& others $v$ Cabinet Secretary for the Ministry of Health \& others [2016] eKLR.

63 KELIN, Mapping the constitutional provisions on the right to bealth, 2018, 18. 


\section{Quality}

According to General Comment 14, health facilities, goods and services must also be scientifically and medically appropriate and of good quality. ${ }^{64}$ This requires, inter alia, skilled medical personnel, scientifically approved and unexpired drugs and hospital equipment, safe and potable water, and adequate sanitation. ${ }^{65}$

The theme of quality of healthcare is a central aspect of the right to health discourse and evidence from studies shows that gaps in the quality of care contributes to complications and death. ${ }^{66}$

Quality is a part of what is often referred to as the 'iron triangle' in which access, cost and quality are the predominant themes that need to be addressed in any attempts to improve a healthcare system. ${ }^{67}$ Therefore, the theme of quality in healthcare is a critical aspect to the full realisation of the right to health and as posited by Adindu, to provide healthcare services without concern for quality is unprofessional and potentially deadly. ${ }^{68}$

The Act does not define quality, however, its definition of healthcare services envisages an understanding of quality in healthcare. ${ }^{69}$

Healthcare services has been defined in the Act as follows:

the prevention, promotion, management or alleviation of disease, illness, injury, and other physical and mental impairments in individuals, delivered by health care professionals through the health care system's routine health services, or its emergency health services. ${ }^{70}$

Based on this definition, it can be concluded that the Act envisions the establishment of mechanisms that ensure prevention, promotion, management

CESCR General Comment No 14, para.12 (d).
CESCR General Comment No 14, para.12 (d).

-World Health Organisation, Standards for improving the quality of care for children and young adolescents in bealth facilities, 2018, 6. -<http://apps.who.int/iris/bitstream/handle/10665/272346/9789241565554-eng. pdf?ua=1 $>-\quad$ on 23 March 2020.

${ }^{67}$ Carroll A, 'The 'iron triangle' of health care: Access, cost and quality' JAMA Forum, 3 October 2012 -<https://newsatjama.jama.com/2012/10/03/jama-forum-the-iron-triangle-of-health-care-accesscost-and-quality/. >- on 23 March 2020.

68 Anthonia A, 'Assessing and assuring quality of healthcare in Africa' 3(1) African Journal of Medical Science, 2010, 1.

69 Ouma S, 'A review of the Health Act 2017 from an access, quality \& cost paradigm', KELIN Workshop On Article 43(1): Strategic Litigation and Discourse on the Right to Health, Limuru, 29 September 2017, 17 -<https://papers.ssrn.com/sol3/papers.cfm?abstract_id=3047970>- on 23 March 2020.

70 Section 2, Health Act (Act No 21 of 2017). 
and alleviation of diseases and impairment. It further recognises the role of regulatory bodies in meeting the outlined objectives of the Act and promoting access to quality. ${ }^{71}$ These salient features of the Act on quality of health-care are analysed below.

The Act makes provision for accountability through regulatory apparatuses. Due to the rights provided by the Act, there are implied duties and duties demand accountability. ${ }^{72}$ To this end, the Act tasks regulatory bodies with the mandate of holding accountable health professionals consequently ensuring quality in their service provision. Additionally, the regulatory bodies are, for instance, charged with: ensuring that standards of training and institutions providing education meet the needs of service delivery; ${ }^{73}$ developing and ensuring compliance on professional standards on registration; and licensing of individuals in the healthcare sector. ${ }^{74}$

Further, Sections 16 and 18 create the offices of the Director General and County Director of Health whose main mandate centre on quality-assurance in the Kenyan healthcare system. ${ }^{75}$

As per Section 15 (1) (b), the Ministry of Health 'shall develop and maintain an organisational structure of the Ministry at the national level comprising of technical directorates.' These directorates are then mandated with dealing with matters such as medical services, nursing, pharmaceutical services and public health. ${ }^{76}$ As the directorates are technical in nature, it can be concluded that they will have the capacity to deal with the said matters on an expert level consequently ensuring quality.

Furthermore, the Act establishes the Kenya Health Professions Oversight Authority. ${ }^{77}$ The Authority's mandate includes: maintaining a register of all health professionals; receiving and facilitating resolution of complaints from patients, aggrieved parties and regulatory bodies; and ensuring the necessary standards for health professionals are not compromised. ${ }^{78}$

\footnotetext{
71 Ouma S, 'A review of the Health Act 2017', 17.

72 Potts H, Accountability and the right to the bighest attainable standard of bealth, Human Rights Centre at University of Essex, 2008 -<http://repository.essex.ac.uk/9717/1/accountability-right-highestattainable-standard-health.pdf. >- on 23 March 2020.

73 Section 15 (j), Health Act (Act No 21 of 2017).

74 Section 15 (1), Health Act (Act No 21 of 2017).

75 Section 17 and 19(5), Health Act (Act No 21 of 2017).

76 Section 18, Health Act (Act No 21 of 2017).

77 Section 45, Health Act (Act No 21 of 2017).

78 Section 48, Health Act (Act No 21 of 2017).
} 
Section 62 establishes a single regulatory body for health products and health technologies. ${ }^{79}$ Examples of this body's functions are licensing health products and technologies, licensing manufacturers and distributors, conducting testing and inspection of manufacturing and distribution facilities and conducting clinical trials. ${ }^{80}$ This means that the Kenya Medical Supplies Authority is subject to the regulatory body created in Section 62, which signifies more checks and balances in the procurement process of health products and technologies. ${ }^{81}$

Further, Section 66 of the Act sets standards for the sale of medicine, vaccine or other health product or technology to members of the public:

Any medicine, vaccine or other health product and technology intended for sale to members of the public shall be eligible for licensing only if - after due assessment, it is found to achieve the therapeutic or the intended effect it claims to possess or which may reasonably be attributed to it; it is sufficiently safe under the normal conditions of use; it is made and packaged according to satisfactory standards.

Accountability for the right to health requires that in the event of a violation of this right, there should be a complaints mechanism and the availability of effective remedies. ${ }^{82}$ The Act has recognised this right by stating that, 'any person has a right to file a complaint about the manner in which he or she was treated at a health facility and have the complaint investigated properly. ${ }^{93}$ It then places an obligation on both the national and county governments to ensure the availability of complaints procedures in health facilities. ${ }^{84}$

Before the Act was enacted, the Kenya Medical Practitioners and Dentists Board, a creation of the Kenya Medical Practitioners and Dentists Act, was the body mandated with receiving complaints. 85 This board ensured the provision of quality and ethical health-care through appropriate regulation, training, registration, licensing, inspections and professional practice. The procedure for filing complaints before the board was set out in the Code of Professional Conduct and Discipline.86 The Board as a complaint system was held by the court to be insufficient in the case of Kenya Hospital Association t/a Nairobi Hospital v Medical Practitioners and Dentists Board \& 4 others, where the High Court

\footnotetext{
Section 62, Health Act (Act No 21 of 2017).

Section 63, Health Act (Act No 21 of 2017).

Section 67, Health Act (Act No 21 of 2017).

Potts H, Accountability and the right to the bighest attainable standard of bealth, 5 .

Section 14, Health Act (Act No 21 of 2017).

Section 14 (2), Health Act (Act No 21 of 2017).

Medical Practitioners and Dentists Act (Cap 252 of 2012).

Code of Professional Conduct and Discipline, Ged, 2012.
} 
ordered that the Medical Practitioners and Dentists Act be reviewed to curb continued death of patients under the care of hospitals due to negligence. 87

Since the presence of effective complaints and redress mechanisms in the healthcare system is one of the key indicators of quality in the system-by providing for a body that has the mandate of receiving and facilitating the resolution of complaints - the Act ensures that there is accountability in both the processes and outcomes of Kenya's health system.

\section{Conclusion}

The AAAQ framework's elements are predominant in the Act. The provisions of the Act such as the presence of state obligations; accountability and regulatory apparatuses; and complaints redress mechanisms clearly denote the presence of the AAAQ framework's controls. However, the Act is not express on some principles such non-discrimination and gender sensitivity that are fundamental to a functioning health system.

Be that as it may, the Act has an extensive and targeted set of provisions that deal with availability, accessibility, acceptability and quality. If these provisions are implemented and enforced, there will be a significant and meaningful improvement of healthcare in Kenya resulting in the realisation of the right to the highest attainable standard of health.

Accordingly, the government needs to take active measures to implement the AAAQ framework's standards as featured in the Act, which can be summarised as mainly entailing the provision of an enabling environment as outlined in Section 6 (3). It is acknowledged that Kenya is a developing country with limited resources and that there is constant competition of needs. However, the AAAQ framework sets bare minimum requirements for a functioning health system. Therefore, with proper planning and ensuring the existence of effective accountability mechanisms in health expenditure, revenue collection and the overall monitoring of processes and outcomes, the government should be able to bring changes to the 'sick' health sector and improve quality in its health system.

Kenya Hospital Association t/ a Nairobi Hospital v Medical Practitioners and Dentists Board \& 4 others, (2018) eKLR. 